\title{
Fasting Serum Insulin Levels in Childhood
}

\author{
D. B. GRANT \\ From the Institute of Child Health, Guilford Street, London W.C.1
}

There is little published information on insulin levels in normal children. Ehrlich and Bambers (1964) found the fasting plasma insulin levels of 6 normal children to be similar to adult levels. Slone, Soeldner, Steinke, and Crigler (1966) have reported low fasting serum insulin levels in 13 normal children between the ages of 3 and 9 years.

This paper describes the fasting immuno-reactive insulin and blood glucose concentrations in 86 European children who had been admitted to hospital for elective surgical procedures. Insulin and glucose levels in 9 premature infants and 12 young adults are also given.

\section{Subjects and Methods}

Children. The group of children consisted of $\mathbf{5 0}$ boys and 36 girls, and their ages ranged from 3 months to 14 years. All the children were well and had been leading relatively normal lives before admission. None was considered to need either medical investigation or medical treatment. The conditions for which the children were admitted to hospital are shown in Table I.

The distribution of the children's weights expressed as centile weight (Tanner, 1958) is shown in Table II. The difference between the numbers of children in each centile group and the expected numbers is not statistically significant $(p>0.05)$. In most of the older children sexual development was assessed (Tanner, 1955). Almost all the children over the age of 11 years showed evidence of the onset of puberty.

Fasting blood specimens were collected before breakfast on the morning after admission to hospital, after a period of fasting which varied between 8 to 14 hours. Blood was obtained by finger-prick or heelprick at the same time as blood was collected for a preoperative haemoglobin estimation. Care was taken to avoid haemolysis.

Adults. Venous blood was collected from 12 young adults after an overnight fast.

Premature infants. Blood was collected by heelprick from 9 infants with birthweights below $2500 \mathrm{~g}$. The birthweights of 7 of these infants were compatible

Received September 23, 1966. with gestational age. The blood was collected 3 hours after a feed, at the same time as blood was collected for $\mathrm{Hb}$ estimation. All the infants were less than 6 weeks old, were gaining weight, and were about to be discharged from the nursery.

Capillary blood was collected as this is a much simpler procedure in small children than a venepuncture, particularly if multiple samples are required. It has been found that, providing haemolysis is avoided, insulin levels in venous and capillary samples collected at the same time correlate well (Fig. 1). Providing insulin levels are not changing rapidly, the speed at which a capillary specimen is obtained does not seem to be important.

Serum, rather than heparinized plasma, was used for the insulin studies, as it is difficult to control the heparin content of capillary samples and high concentrations of heparin were found to interfere with the immunoassay.

Serum was obtained by allowing specimens to clot for 9 hours at $4^{\circ} \mathrm{C}$. Serum insulin was determined by a modification of the double-antibody immunoassay

TABLE I

Conditions for Which Children Were Admitted to Hospital

\begin{tabular}{|c|c|c|c|c|c|c|}
\hline \multicolumn{6}{|c|}{ Condition } & \multirow[b]{2}{*}{$\begin{array}{r}\text { No. } \\
15 \\
11 \\
7 \\
7 \\
7 \\
7 \\
7 \\
5 \\
7 \\
10 \\
3\end{array}$} \\
\hline $\begin{array}{l}\text { Hernia or hydro } \\
\text { Hypospadias } \\
\text { Undescended te } \\
\text { Hare-lip or cleft } \\
\text { Skin graft } \\
\text { Haemangioma } \\
\text { Bat ears . } \\
\text { Syndactyly } \\
\text { Old polio: dislo } \\
\text { Miscellaneous } \\
\text { Normal . . }\end{array}$ & $\begin{array}{l}\text { ocele } \\
0 \text { is } \\
\text { estis } \\
\text { t palate } \\
\ldots \\
\ldots \\
\ldots \\
\ldots\end{array}$ & $\begin{array}{l}\cdots \\
\cdots \\
\cdots \\
\cdots \\
\text { ip } \\
\cdots\end{array}$ & $\begin{array}{l}\cdots \\
\cdots \\
\cdots \\
\cdots \\
\cdots \\
\cdots \\
\cdots \\
\cdots\end{array}$ & $\begin{array}{l}\cdots \\
\cdots \\
\cdots \\
\cdots \\
\cdots \\
\cdots \\
\cdots \\
\cdots\end{array}$ & $\begin{array}{l}\cdots \\
\cdots \\
\cdots \\
\cdots \\
\cdots \\
\cdots \\
\cdots \\
\cdots\end{array}$ & \\
\hline
\end{tabular}

TABLE II

Distribution of Centile Weights of Children

\begin{tabular}{c|c|c|c|c|c|c}
\hline Centile & $<10$ & $10-25$ & $25-50$ & $50-75$ & $75-90$ & $>90$ \\
\hline $\begin{array}{l}\text { Actual number } \\
\text { Expected number }\end{array}$ & $\begin{array}{c}15 \\
(8 \cdot 6)\end{array}$ & $\begin{array}{c}13 \\
(12 \cdot 9)\end{array}$ & $\begin{array}{c}12 \\
(21 \cdot 5)\end{array}$ & $\begin{array}{c}19 \\
(21 \cdot 5)\end{array}$ & $\begin{array}{c}17 \\
(12 \cdot 9)\end{array}$ & $\begin{array}{c}10 \\
(8 \cdot 6)\end{array}$ \\
\hline
\end{tabular}

$\chi^{2}=10 \cdot 78 ; p>0.05$. 


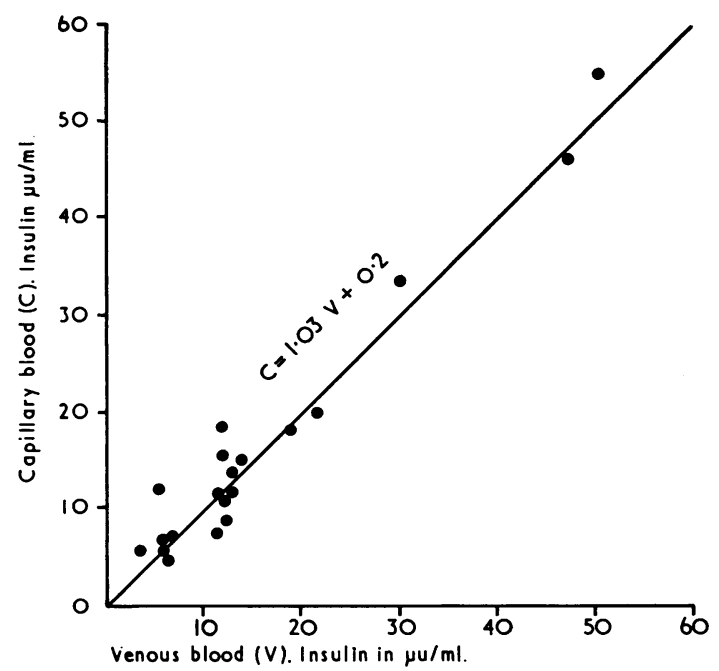

FIG. 1.-Relation between serum insulin concentration of capillary and venous samples.

described by Morgan and Lazarow (1963). One batch of anti-insulin serum (Burroughs Wellcome $K$ 5549) was used. 16 hours before the addition of ${ }^{125} I$ ox-insulin (Radiochemical Centre, Amersham 1M 38) $0.1 \mathrm{ml}$. serum or human insulin standard was added. 16 hours were allowed for precipitation by the second antibody and the assay system contained EDTA in a final concentration of $0.01 \mathrm{M}$. Under the conditions used, 4 $\mu$ units standard insulin produced a fall in the antibodybound ${ }^{125} \mathrm{I}$ insulin of approximately $60 \%$.

The results for the recovery of human insulin added to serum are shown in Table III. The results obtained with dilutions of serum were always consistent with the results obtained with undiluted serum. Fasting serum added with the second antibody to a system containing a relative excess of anti-insulin serum had no appreciable effect on the precipitation of ${ }^{125} \mathrm{I}$ insulin.

The insulin determinations were repeated in duplicate after an interval of weeks or months. The values given are the mean values from 2 or 3 assays. A control fasting specimen was included in each assay. The mean value for 72 results from 36 consecutive assays was $10 \cdot 5 \mu \mathrm{u} / \mathrm{ml}$. (SD $\pm 2 \cdot 0 \mu \mathrm{u} / \mathrm{ml}$.: range 5-15 $\mu \mathrm{u} / \mathrm{ml}$.).

\section{TABLE III}

\section{Recovery of Human Insulin Added to Serum}

\begin{tabular}{c|c|c|c}
\hline $\begin{array}{c}\text { Insulin } \\
\text { Added } \\
(\mu \mathrm{u} / \mathrm{ml} .)\end{array}$ & $\begin{array}{c}\text { No. of } \\
\text { Recoveries }\end{array}$ & $\begin{array}{c}\text { Mean Recovery } \\
\pm S D(\mu \mathrm{u} / \mathrm{ml} .)\end{array}$ & $\begin{array}{c}\text { Range } \\
(\mu \mathrm{u} / \mathrm{ml} .)\end{array}$ \\
\hline 10 & 13 & $10 \pm 2 \cdot 5$ & $5-15$ \\
20 & 13 & $20 \pm 2 \cdot 8$ & $13-24$ \\
30 & 13 & $29 \pm 2 \cdot 6$ & $25-32$ \\
40 & 13 & $39 \pm 3 \cdot 3$ & $32-45$ \\
60 & 6 & $61 \pm 3 \cdot 7$ & $57-67$ \\
\hline
\end{tabular}

Blood glucose was measured on specimens collected into bottles containing sodium fluoride and potassium oxalate, using a modification of the glucose oxidase method described by Huggett and Nixon (1957).

The statistical significance of differences between mean values and the significance of regression coefficients was tested by Student's ' $t$ ' test.

\section{Results}

Blood glucose. Fasting blood glucose was measured in 85 of the 86 children. The values ranged from $43 \mathrm{mg}$. $/ 100 \mathrm{ml}$. to $95 \mathrm{mg}$. $/ 100 \mathrm{ml}$., with a mean value of $73 \mathrm{mg} . / 100 \mathrm{ml}$. The slope of the regression line calculated for blood glucose on age (blood glucose $(\mathrm{mg} . / 100 \mathrm{ml}$. $)=0.83$ age (years) + $67 \cdot 7)$ is statistically significant $(p<0.01)$. This rise with age is similar to the rise in total reducing substances reported by Mayer (1951).

The mean blood glucose in the 9 premature infants was $69 \mathrm{mg} . / 100 \mathrm{ml}$. (49-84 mg. $/ 100 \mathrm{ml}$.), and in the 12 adults $77 \mathrm{mg} . / 100 \mathrm{ml}$. (55-90 mg./100 ml.).

Serum insulin. The fasting serum insulin in the 86 children ranged from undetectable levels to $32 \mu \mathrm{u} / \mathrm{ml}$., with a mean value of $8 \mu \mathrm{u} / \mathrm{ml}$. The distribution of the insulin values in different agegroups and the mean values in the different groups is shown in Fig. 2. The mean values show a progressive rise with age. The regression line for insulin on age was calculated for the complete group of children. The slope of this line is statistically highly significant (insulin $(\mu \mathrm{u} / \mathrm{ml})=$.1.02 age (years) $+2 \cdot 1 ; p<0.001)$. The regression lines for boys and girls are almost identical, and the slope of the line for children under 7 does not differ significantly from the slope for children over 7 .

Significant correlations between insulin and bodyweight $(p<0.001)$, and insulin and blood glucose $(p<0.01)$ were also found. There was no significant correlation between the length of fast (8-14 hours) and the insulin concentration.

The fasting insulin values in the 12 adults ranged from 6 to $20 \mu \mathrm{u} / \mathrm{ml}$., with a mean value of $10 \mu \mathrm{u} / \mathrm{ml}$. This is significantly lower than the mean value for children over the age of 11 years $(p=0.02)$.

The insulin values found in 9 premature infants after a 3-hour fast ranged from 15 to $43 \mu \mathrm{u} / \mathrm{ml}$., with a mean value of $29 \mu \mathrm{u} / \mathrm{ml}$. This value is significantly higher than the mean value for children over the age of 11 years $(p<0.001)$.

\section{Discussion}

It would have been desirable to study healthy children at home, but as this was not possible the 


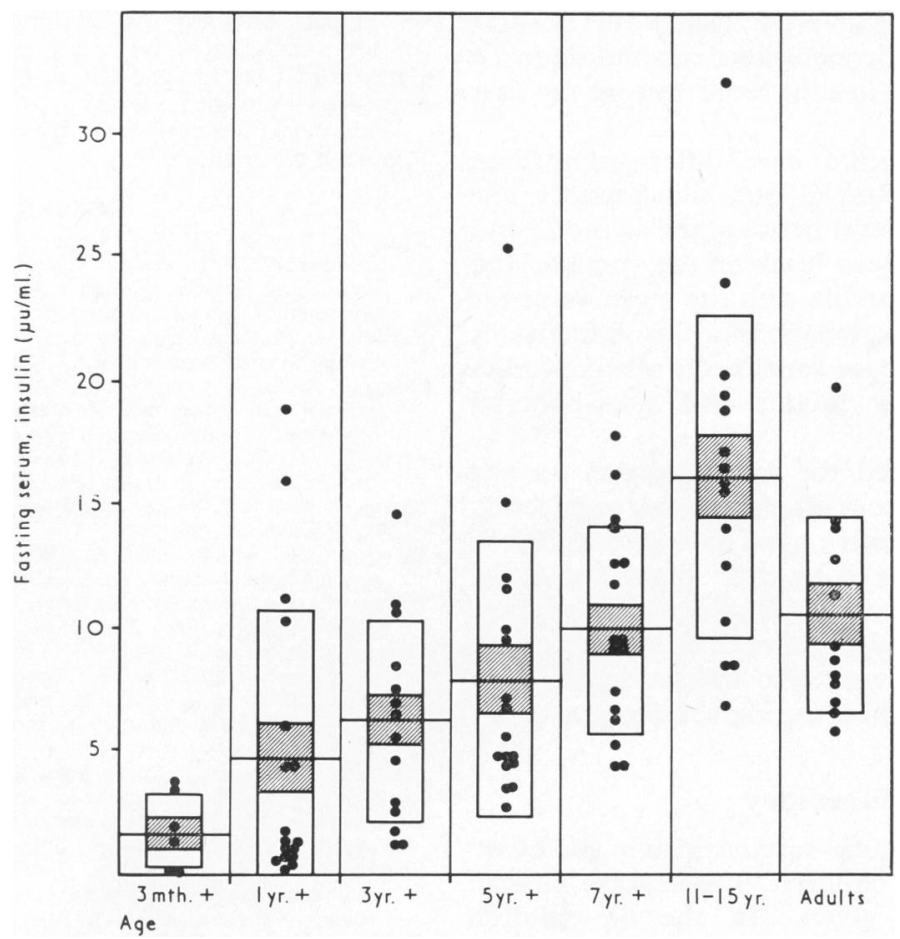

FIG. 2.-The insulin concentrations and mean values in different age-groups. Open rectangles $= \pm S D$, hatched rectangles $= \pm S E$.

survey was confined to hospital patients. Samples were collected within 24 hours of admission and only healthy children were studied, in an attempt to minimize any possible effects of illness, an unfamiliar diet, or restricted activity.

The data presented here suggest that the fasting serum insulin concentration rises progressively with increasing age. It is unlikely that this finding is due to changes in the precision of the assay during the period of study, as the assay conditions were kept constant and a control specimen gave consistent results. Specimens were collected from the different age-groups in a random order, and the results of repeated assays agreed closely with the initial assay results. Serum may interfere with the doubleantibody assay by modifying the rate of precipitate formation (Soeldner and Slone, 1965). Under the conditions used, no appreciable non-specific effects were noted, and it is considered unlikely that the results are due to age-dependent serum effects on precipitation.

The interpretation of fasting insulin levels is difficult, as the factors controlling these levels are still incompletely understood. Low insulin levels have been described in adults after prolonged fasting
(Yalow and Berson, 1965) and the correlation between fasting insulin level and age or body weight found in this study may merely reflect the ratio between body size and length of fast. Raised fasting insulin levels associated with an exaggerated serum insulin response to glucose have been reported in obese adults (Samaan, Brown, Fraser, and Trayner, 1965), and in patients with hypertension (Welborn, Breckenridge, Rubinstein, Dollery, and Fraser, 1966) and ischaemic heart disease (Peters and Hales, 1965), and fasting insulin levels may be related to tissue sensitivity to insulin.

The difference between the mean fasting insulin levels in the older children of 11-15 years and adults is of interest. Acromegaly (Beck, Schalch, Parker, Kipnis, and Daughaday, 1965), pregnancy (Spellacy and Goetz, 1963), and the administration of corticosteroids (Perley and Kipnis, 1966) are associated with increased serum insulin responses to glucose. The apparent rise in fasting insulin at the time of puberty may reflect the endocrine changes or growth acceleration which occur at this time. The relatively high insulin values found in the premature infants are hardly comparable with the values found in older children, as the infants were all having a 
high calorie intake and were fasted for a short period of time. No conclusions can therefore be drawn on changes in insulin levels during the first year of life.

The findings reported here differ from those reported by Slone et al. (1966), who found a low mean fasting insulin level between the ages of 3 and 9 years and higher mean levels in the younger and older children, comparable with the mean value for adults. A possible explanation for this difference is that their series may have contained a relatively high proportion of young infants and post-pubertal children.

Loeb (1966) studied the rate constants for the disappearance of glucose after intravenous injection and found a progressive rise during the first 6 months of life, followed by little change until the onset of puberty when the rate constant fell to adult levels. It seems possible that the change in insulin levels reported here may also indicate changes in carbohydrate metabolism during childhood.

\section{Summary}

Fasting serum immuno-reactive insulin and blood glucose values in 86 children, 9 premature infants, and 12 adults are given. In the 86 children fasting serum insulin appeared to rise progressively with increasing age. Blood glucose also showed a significant rise with age. Some possible implications of this are discussed.

I wish to thank the nursing staff of The Hospital for Sick Children and Queen Charlotte's Hospital for their helpful co-operation, Mrs. S. Chalkley and Mrs. D. Jackson for assistance with the glucose estimations, Dr.
G. Howard Smith of the Wellcome Research Laboratories for supplying a human insulin standard, and Dr. Barbara E. Clayton and Dr. R. W. H. Edwards for their encouragement and advice.

This work was supported by a grant from the Medical Research Council. REFERENCES

Beck, P., Schalch, D. S., Parker, M. L., Kipnis, D. M., and Daughaday, W. H. (1965). Correlative studies of growth hormone and insulin plasma concentrations with metabolic abnormalities in acromegaly. f. Lab. clin. Med., 66, 366.

Ehrlich, R. M., and Bambers, G. (1964). Immunologic assay of insulin in plasma of children. Diabetes, 13, 177.

Huggett, A. St. G., and Nixon, D. A. (1957). Use of glucose oxidase, peroxidase and $\mathrm{O}$-dianisidine in determination of blood and urinary glucose. Lancet, $2,368$.

Loeb, H. (1966). Variations in glucose tolerance during infancy and childhood. F. Pediat., 68, 237.

Mayer, J. B. (1951). Über den Blutzuckerspiegel im Kindesalter. Z. Kinderheilk., 69, 232.

Morgan, C. R., and Lazarow, A. (1963). Immunoassay of insulin: two antibody system. Diabetes, 12, 115.

Perley, M., and Kipnis, D. M. (1966). Effect of glucocorticoids on plasma insulin. New Engl. F. Med., 274, 1237.

Peters, N., and Hales, C. N. (1965). Plasma-insulin concentrations after myocardial infarction. Lancet, 1, 1144.

Samaan, N., Brown, J., Fraser, R., and Trayner, I. (1965). Effect of obesity and of starvation on insulin activity. Brit. med. $\mathcal{F}$., $1,1153$.

Slone, D., Soeldner, J. S., Steinke, J., and Crigler, J. F. (1966). Serum insulin measurements in children with idiopathic spontaneous hypoglycemia and in normal infants, children and adults. New Engl. F. Med., 274, 820.

Soeldner, J. S., and Slone, D. (1965). Critical variables in the radioimmunoassay of serum insulin using the double antibody technic. Diabetes, 14, 771.

Spellacy, W. N., and Goetz, F. C. (1963). Plasma insulin in normal late pregnancy. New Engl. F. Med., 268, 988.

Tanner, J. M. (1955). Growth at Adolescence, pp. 32-37. Blackwell Scientific Publications, Oxford.

- (1958). Standards for growth of normal children. In? Modern Trends in Paediatrics, ed. A. Holzel and J. P. M. Tizard, p. $330 . \quad$ Butterworth, London.

Welborn, T. A., Breckenridge, A., Rubinstein, A. H., Dollery, C. T. and Fraser, T. R. (1966). Serum-insulin in essential hypertension and in peripheral vascular disease. Lancet, 1, 1336.

Yalow, R. S., and Berson, S. A. (1965). Dynamics of insulin secretion in hypoglycemia. Diabetes, 14, 341. 